SHS Web of Conferences 23, 01003 (2016)

DOI: $10.1051 /$ shsconf/20162301003

(C) Owned by the authors, published by EDP Sciences, 2016

\title{
CONTESTING AND REJOICING THE COLONIAL DISCOURSE: AS REFLECTED IN A MALAY POSTCOLONIAL NOVEL WRITTEN DURING THE BRITISH COLONIALIZATION
}

\author{
Sohaimi Abdul Aziz \\ School of Humanities \\ Universiti Sains Malaysia \\ Penang, Malaysia \\ soaazz@usm.my
}

\begin{abstract}
From 1511 to 1957, Malaysia was once colonized by the colonial discourse which was an instrument of power of the colonialist. The colonial discourse is a discourse from the colonialist suppressing and degrading the colonized. Consequently, several uprisings by the Malay nationalists against the colonialist had been recorded in Malaysian history with regards to the colonial discourse. At this juncture, the colonial supremacy had been contested politically. What about the Malay authors during the period of time? Did they partake in this contestation? If so, what was the contestation and how the contestation was carried out? This paper aims to discuss the colonial discourse and how it has been contested in the only Malay postcolonial novel written by Ishak Haji Muhammad while the English was still in Malaysia (Malaya). Ishak can be regarded as the only Malay author who was brave enough to contest no only the colonialist's discourse but also the Malay rulers who were also seen collaborating with the colonialist in stretching and strengthening the colonial discourse.
\end{abstract}

Keywords: colonial discourse; postcolonial discourse; Malay novel; Ishak Haji Muhammad;

\section{INTRODUCTION}

For almost 500 years The Malay Peninsular was colonized by major European powers, namely Portugal, Holland and England. Western colonization began with the arrival of the Portuguese in Malacca in 1511, lasting for 130 years. This was followed by the Dutch in 1641 who extended their influence for a while to Naning District and Kuala Selangor. The British came after the Dutch. The British extended their colonial empire by befriending Sultan Abdulah Mukaram Shah and persuading him to hand over the island of Penang to them. The English persuaded Sultan Husain Shah to hand over Singapore to them. By the English-Dutch agreement of 1824, Malacca was fully under British control. Other states were then "protected" upon the request of the Malay rulers themselves. Later the Japanese colonized the Peninsular for three and the half years, during the Second World War. 


\section{COLONIAL AND POSTCOLONIAL DISCOURSE}

The colonialists brought with them their set ideas about the nations and the states that they colonized. Their attitude was formed based on their strongly held belief in their superiority and perfection as civilized states and nations. They believed that only their cultures and their states were civilized. Hence it was ingrained in their mind that their way of thinking, their culture and their race were perfect and supreme compared to those in the countries that they colonized. This belief was known as ethnocentrism and it blended extremely well with another way of thinking, called orientalism. Edward Said (1978: 3) described :

\section{Orientalism as a Western Style for dominating, structuring and having authority over the Orient.}

Said held that orientalism was a compendium of ideas, theories, beliefs and clichés of the West regarding Eastern cultures and values. In other words, the colonial discourse under scrutiny is a discourse of the colonialists solidly based not only on orientalism but also on ethnocentrism.

Orientalism reeks of politics, racialism, colonialism and it is almost wholly ethnocentric. Orientalism and ethnocentrism are basis for the development of colonial discourse encompassing the colonized land which they called 'the Orient.' This category of discourse is clearly biased as it hinges on narrow and negative opinion of a colonized race and its culture. The colonial discourse is inhuman, smacking of repressive politics and strongly rooted in racialism. Orientalism and ethnocentrism become the important ingredients of postcolonial discourse.

Postcolonial discourse is a discourse of an engagement and contestation of colonial discourse. As mentioned above, colonial discourse is a discourse which suppressed and degraded the colonized. One of the reaction to this suppression is to write back to the colonizer and to contest the postcolonial discourse which it is also the white supremacy and inhuman in nature. This discourse clearly contained the feelings and voices of the indigenous people (the colonized), the existence of which was completely disregarded before. These voices were beginning to challenge the authority and the grandness of the cultures of the colonial powers. The postcolonial discourse could be found in literature. It encompasses literary works during and after colonial times. In other words, postcolonial discourse is a discourse that resulted directly as a reaction to colonialism.

\section{PUTERA GUNUNG TAHAN and ISHAK HAJI MUHAMMAD}

Apart from actual physical opposition against the supremacy of the British, there were also more subtle forms of contestation in the form of literary works such as novels. This kind of contestation is more than anti-colonial act because it involves cultures which 
are inevitably hybridized, involving a dialectical relationship between European anthology and epistemology and the impulse to create or recreate independent local identity (Tiffin, 1995: 95). Postcolonial novel is a novel that reacts toward the process of production of knowledge of the colonized or the Other. The contestation against the colonial discourse not only occurs in novels written after the colonization but also during the colonization. In others words, postcolonial novel is literary writing that reacts to the colonial discourse; an attempt to critique or contest the colonial discourse. This novel involves the process of "writing back to the Center"; an acts of challenging and contesting the colonial discourse and it has been written during or after colonization. Thus, postcolonial novel is not an anti-colonial novel but a novel which reacts to the experience of colonization and it is most appropriate to say as a contestation and resistance to the colonial discourse. The development of Malay postcolonial novels started with emergence of a novel entitled Putera Gunung Tahan (The Prince of Mount Tahan) by Ishak HajI Muhammad in 1937.

\section{ISHAK HAJI MUHAMMAD}

The arising of Malay intellectual groups as a result of getting better education has awakened a realization of the hidden agenda behind the Western hegemony and this realization was recorded in the form of creative writings. Apart from creative writings, newspapers and magazines also became the channels through which this realization was voiced. The 1920's and 1930's was the era that witnessed the emergence of a group openly voicing its opinion on things not related to Islamic inspirations. Its emergence was related to the spread of anti-colonial spirit across the whole of the Malay Peninsular( Roff:1975:161). The group produced creative and non-creative writings. The noncreative writings could be found in newspapers and magazines. For example mild criticisms of the government (British) were made in Utusan Melayu (Roff:203). Apart from writings in essay forms and descriptive forms there were also creative writings such as Melor Kuala Lumpur (The Jasmin of Kuala Lumpur)(1930) by Harun Mohd. Amin (Harun Aminurashid). The novel did not actually criticize the government, rather it contained advice for the Malays as a race to work hard so as to achieve good standing in society. However the emergence of the novel Putera Gunung Tahan (The Prince of Mount Tahan) written by Ishak Haji Muhammad brought a different and new trend, more refreshing and daring in its reaction towards the English colonization. Putera Gunung Tahan_brought a new light in the fight to challenge the authority of British colonialism.

Ishak Haji Muhammad was a left leaning nationalist who was involved in political movements. He was the leader of a political party called Parti Kebangsaan Melayu Malaya (P.K.M.M.) or Malayan Malay Nationalist Party, the leader of the Labour Party and the chairman of the Socialist Front. He stood for election in the Federation of Malaya Parliamentary election.(Sharom Husain:182-183). Apart from being involved in politics he was also a prolific writer.

As a leftist nationalist, voicing out sharp criticisms against the colonialists was ingrained in him. His first novel with the title Putera Gunung Tahan was written 20 years before the Federation of Malaya gained its independence from the English. Ishak used the 
pen as a means of demonstrating and consolidating the change of feelings towards the English. Through Putera Gunung Tahan, Ishak challenged the authority of the English. As far as Ishak was concerned the English was not as perfect as they were thought to be. His loud and clear criticism of the colonialists was chanelled systematically and artfully. Putera GunungTahan could be regarded as a postcolonial novel even though it was written 20 years before the Malay States (now Malaysia) became independent.

Putera Gunung Tahan was the first novel written by Ishak before World War Two. This novel is the first Malay postcolonial novel. The novel was set in Pahang, a state that was well noted for the anti-British stand taken by its leaders notably Datuk Bahaman, Tok Gajah and Mat Kilau. The plot in the novel was interwoven with the history of the anti-British stand. Clearly the novel carried with it the spirit of well-known historical figures of Pahang and the names of important figures like Bahaman who carried the title 'Orang Kaya Semantan' (The Rich Man of Semantan) and Tok Gajah were mentioned in the novel. The lady who gave birth to Ratu Bongsu who later ruled the top of Gunung Tahan was also said to have been married to a Pahang dignitary. In other words the anti-British spirit of the Datuk Bahaman group was stoked up by Ishak in the novel.

The novel started with two English adventurers, Tuan Robert and Tuan William who were specially sent from England to look into the possibility of developing the top of Gunung Tahan as a tourist resort. In short this mission was purely of economic consideration, both for the sponsor and for themselves. In their quest Tuan Robert was captured by a group of aborigines, taken into the thick jungle and appointed as the leader of the aborigines with the title Datuk Batin Putih ( The White Headman ). When Tuan Robert belittled the ability of the aborigines to cast a spell, he was given a love potion which made him fall head over heel with an aborigine girl. In the meantime Tuan William who had lost his friend, tried to trace him. Later, Tuan William was found by a male spirit of the forest and taken to the top of Gunung Tahan to meet Ratu Bongsu who was the ruler of the mountain top.

Ishak used the character Tuan Robert to show how the British bragged about how they brought benefits to Malay leaders, officers and society. Tuan Robert tried to explain to the old lady whom he met about the good or the advantages the local people enjoyed such as infrastructural progress, good pay given to the Malay rulers and leaders and the Malay society given modern education and a more suitable way of dressing and living. If the British were not there, there would be no civilization. Only the English were capable of bringing civilization to the Malay Peninsular. Among other things Tuan Robert said :

Oh! You and your people have made a very big mistake because so many benefits are brought to your state when the white man protects and rules you. Now your state has become very beautiful, so also have other states such as Perak, Selangor, Negeri Sembilan, Johor, Kedah, Kelantan and Terengganu that are in the Malay Peninsular. All these 
states have progressed and there are now railway lines, many roads, big towns, beautiful offices, roads for cars, telegraph, telephone, and so many more things which I am sure you haven't heard of or let alone see. All these came about with the power of British money, English ingenuity and English administration - translation (Ishak 1973: 35-36).

Tuan Robert and Tuan William believed that the British have brought big and invaluable blessings to the Malays. During a dialogue with Ratu Bongsu Tuan William stated that it was only sensible that the English should advise Malay rulers and leaders and the rulers and leaders must listen to their advice and act accordingly:

I feel it is really fair that the white officer gives such advice because he is highly educated and it is imperative that the Malays merely follow whatever the white man said because of the advantages that could be obtained namely a good name, a high rank and a lucrative salary. Moreover your Highness, it is really wise for the Malays to have full faith in the protection given by the government of my country because next to God, only the government of my country is the strongest and it has perfect administration -translation (Ishak: 79-80).

On another occasion Tuan Robert asked the old lady:

.... but I would like to ask a bit more and that is, why don't you, your husband and a few more people, like the government or protection of the English who are famous throughout the world for their wisdom and bravery! - translation (Ishak: 34). .

In the real setting in the era of the British colonization, such as, British officer R. O. Winstedt (1972:70) belittled the ability of traditional Malay writers to be creative. He regarded Malay writers were only good at copying foreign literature wholesale without attempting to create anything local in nature. Traditional Malay writers were seen as stupid and were only good in taking Hindu and Islamic elements for their creative writing, neglecting to develop their own creativity. In other words, colonial discourse clearly was unacceptable because of the colonialist and racist nature. The colonized people could no longer accept this type of discourse. They have demonstrated their reaction towards colonialism especially towards colonial discourse. 
Through Putera Gunung Tahan, Ishak has contested the colonial discourse. Ishak creatively describes the meaning of colonial discourse in his novel and then contested it and this approach can be seen in the following quotation:

Every white man who came to Malaysia did so to get money and profit and not solely to guide and protect the indigenous people of this country - translation (Ishak: 23-24).

Ishak used the old lady in his novel to satirize the British. Tuan Robert badly wanted from the old lady the skin of a white tiger that he wanted to take back with him. When asked why he was so desirous of the white tiger skin, Tuan Robert replied that he wanted to take the tiger skin with him to show it to the people in England and to tell them that he had met the white tiger and shot it. As proof he would show the tiger skin to the people there. Upon hearing Tuan Robert's reply the old lady quipped:

It seems you intend to lie and cheat the public whereas I heard that the English never tell lies - translation (Ishak: 26-27).).

Ishak had clearly satirized the British who were very proud that they were a civilized race and well respected all over the world. Ishak actually wanted to demonstrate that all the claims were lies. They were an insincere race and all their actions were full of hidden intentions as realized by the old lady when Tuan Robert tried to persuade her to come out of the jungle to lead a better life in order to get hold of the white tiger skin

Ishak then proceeded to criticize the negative influence of the British on the Malays. The issue of free and unrestrained mixing of the sexes received particular attention from Ishak. The adulterous wife of Tuan William was seen by Ratu Bongsu as the product of a free-mixing English society in England. Ratu Bongsu openly asked Tuan William's opinion on the negative side of the British social system, leading his own wife to commit adultery (Ishak:67). As a colonialist, Tuan William proudly said that there was nothing wrong with free-mixing of the sexes. It has been a way of life of modern society. Tuan William was proud that this phenomena was started by the West and it has spread to all societies of the advanced world.

As far as Ishak was concerned the social practice brought by the West was morally lacking. They were not as great as it was widely acclaimed. They were the purveyors of social diseases to Malay Society. As far as Ishak was concerned the British not only disrupted Malay politics but also corrupted the moral of the Malays. Ishak was of the belief that the British colonialist had transgressed upon Eastern norms and social practices (Ishak:6). Ishak perceived that the English could only influence the Malays who were narrow-minded and this type of people could be easily deceived.

Ishak's direct and indirect innuendos and criticisms of the British were contained in the use of the word "Tuan" on the two characters, Robert and William. The Malays who were awed by the greatness of the British were those who have small and narrow mind and refused to accept reality. Heaping the prestigious title of "Tuan" to the likes of 
Robert and William was a reality that was too common in Malay society. The Malays thought very highly of the whites. Ishak wanted to make it clear that the whites whom they respected so highly were ordinary people full of weaknesses, some of them were not only downright stupid but were also arrogant.

The stupidity and arrogance of the whites were mirrored in Tuan Robert. Tuan Robert's attitude of belittling the effectiveness of magic spells and incantations turned against him so much so that he fell head over heel in love with an aboriginal girl of the Sakai tribe, a girl who is lacking socially, culturally and economically compared to the Malays. A more interesting episode was that this Sakai tribe made a fool of Tuan Robert by laying terms and conditions for the marriage. Tuan Robert was required to chase the girl around an ant hill. When Tuan Robert failed to do this he was given a second chance. He was required to climb up a tree so that he could marry the girl he fell in love with. The two preconditions imposed may seem funny but in reality they were degrading a race that was supposed to be highly civilized like the English

\section{REJOICING COLONIAL DISCOURSE}

Ishak Haji Muhammad had very sharp criticisms for the Malay aristocratic groups particularly the Rajas who not only gave in to the wishes of the British but often they were worse than the British. These people were only interested in preserving their selfinterests. They were in league with the British, so as to preserve their positions. The English culture was copied and practiced. Ishak Haji Muhammad could not accept the attitude of the Rajas and using the novel Putera Gunung Tahan_he criticized them when Ratu Bongsu married an British widow who at one time had been treacherous to her husband.

The ending of this novel was the marriage of Ratu Bongsu with Mem William. There can be two interpretations of these events. Seen from one angle the events turned out to be an anticlimax of the whole novel. Right from the beginning it was clear that Ishak completely contested colonialism and the colonialists were regarded as greedy. Why then did Ishak finally accepted the British when Ratu Bongsu would be married to Mem William? Thus, the marriage of Ratu Bongsu who was portrayed as a forceful and enigmatic figure at the top of Gunung Tahan to an English woman was an anticlimax in the novel.

Seen in a different context the marriage is an illustration of the power of colonial discourse over the colonized and this powerful discourse has been used by the Malay rulers to strengthen their position among the Malays and hopefully could be acknowledge by the colonialists. The Malay rulers, such as, Putera Bongsu practiced a way of thinking and living like the British. They wanted to be British because they wanted to share the hegemony of the colonialists and consequently hoping the colonialists will accept them at par. Consequently, the Malay rulers believed that they would had have stronger supremacy over the Malays using the image of the British. Thus the Malay rulers as portrayed by Putera Bongsu in the novel did not fully reject colonial discourse. They used it for their own good. Oi order to stay in power and sustain it, they had to change by 
fitting into a colonial image. Ratu Bongsu believed that he had to admit that he could not resist the colonial discourse in order to hold to the power left.

The marriage of Ratu Bongsu with Mem William clearly strengthen the authority of the English over the local natives because it was obvious that some of the natives were desirous of becoming like them. At one time Ratu Bongsu was against the British but at another moment seemed to get on well with them. At this point the British became the center of authority and he needed the authority in order to rule his people with the blessings of the colonialists. So the struggle against the colonial discourse was left with the ordinary Malays like Ishak Haji Muhammad. In other words, Putera Gunung Tahan is a postcolonial novel which reflects a struggle of a Malay writer such as Ishak Haji Muhammad against colonial discourse of the British and he also criticizes the Malay rulers who were more interested in themselves rather in seriously involved in contesting the inhuman discourse.

\section{CONCLUSION}

From the analysis of the three postcolonial novels it is clear that there existed a wave of contestation to the suppressive colonial discourse. All the three colonial powers namely the Portuguese, the Dutch and the English who controlled the Malay Archipelago at one time planted their respective colonial discourse amongst the local people for the purpose of controlling and making use of these people for their own self interest. The demeaning colonial discourse was contested in the three novels that were discussed. The novel Putera Gunung Tahan was written when the English were still in power in the Malay Peninsular and the feudal system was utilized by the English. The English made use of colonial discourse to continue their colonialism. Since the English were still in power Ishak used the novel to contest colonial discourse. He did this through the characters that he created such as Tuan Robert and Tuan William. This novel also contains elements of ambivalence which reveals the vulnerability of colonial discourse.

\section{REFERENCES}

Ashcroft, Bill, Gareth Griffiths, and Hellen Tiffin. 1998. Key Concepts in PostColonial Studies. London and New York: Routlege.

Tiffin, Helen. 1995. "Post-colonial Literature and Counter-discourse" in Bil Ashcroft, Gareth Griffiths and Helan Tiffin. The Post-Colonial Studies Reader. London and New York: Routledge.

Ishak Haji Muhammad. 1973. Putera Gunung Tahan. Petaling Jaya: Pustaka Budaya Agency.

Roff., William R. 1975. Nasionalisme Melayu. Terj. Ahmad Boestaman. Kuala Lumpur: Penerbitan Universiti Malaya.

Said, Edward W. 1978. Orientalism. London and Henley: Routledge \& Kegan Paul. 
Shaharom Husains (Ed). 1963. Antara Pengarang-Pengarang Novel Melayu dan Karyanya. Singapura: Pustaka Melayu.

White, Hayden. 1992. Tropics of Discourse. Essays in Cultural Criticism. Fifth Printing. Baltimore and London: The Johns Hopkins University Press.

Winstedt, R.O. 1972. A History of Classical Malay Literature. Kuala Lumpur: Oxford University Press. 